inches of the wound healed by primary union, but the remainder was not soundly healed until the end of seven weeks, as a deep sinus continued to discharge pus apparently from behind the trachea. By degrees the superficial veins began to appear and the colour returned to her face, and in two months from the time of operation she had gained in weight two stone, which she has maintained ever since, and is, I suppose, her normal weight when not interfered with by the presence of the tumour.

There is one very interesting point at the present time occupying the attention of surgeons, which is the probability of the occurrence of symptoms resembling myxœedema following the complete excision of the thyroid gland. Sir William Mac Cormac, in his address on Surgery, delivered at Belfast in 1884 , has given a very complete summary of our state of knowledge up to that time on this subject.

The patient was exhibited before the East Anglian Branch of the British Medical Association in October, 1884, and also before the Norwich Medico-Chirurgical Society in March 1885 , up to which time she remained in good health, and showed no signs of any evil effect following the operation.

Norwich.

\section{A CASE OF SO-CALLED CATHETER FEVER.}

BY GEO. C. MACDONALD, M.R.C.S., L.R.C.P., LATE RESIDENT PHYSTCIAN, ROYAL EDINBURGH INFIRMARY.

THE following case is of interest insomuch as it shows that some at least of these so-called cases of catheter fever are septicæmic in origin, and therefore, to a certain extent, capable of control.

James $M-$, aged fifty-five, a factory hand, was admitted into the Royal Edinburgh Infirmary for hæmaturia and frequent calls to micturate. His present illness commenced as a severe pain in the left lumbar region ten weeks before admission, for which he can assign no cause. The pain commenced on micturition, but subsided towards the close of the act. The desire was so great that he was forced to pass his urine, on an average, every hour and a half. The urine was clear, there being no blood or thickness noticeable. At times he would have a severe pain shooting down into the left groin and testicle, accompanied with a distinct rigor. This eondition continued for fourteen days, when the desire to micturate became so aggravated that he was forced to seek relief every half hour. Eight weeks after his first attack of pain it suddenly left him, and he now, for the first time, noticed that his urine became tinged with blood towards the last few drops, accompanied by a severe scalding pain in the penis, but there was no pain on exercise. The blood now increased in amount until the urine became as black as porter. He had been under treatment for the last two months, but his medical man advised him to seek further advice. The family and personal history is good.

His present condition is as follows: Confined to bed, general development and muscularity fair ; height, $5 \mathrm{ft}$. $81 \mathrm{in}$. weight, 10st.; temperature $98^{\circ}$ to $99^{\circ}$; complains of slight sweats; skin soft and normal in colour; lungs normal for age. Genito-urinary system: Urine, dark, due to admixture of blood; reaction acid; sp. gr., 1009 to 1010 ; deposit of urates; amount varies from 90 to 100 ounces in the twenty-four hours; albumen present, due to the blood. The microscope reveals a great number of blood-discs and some amorphous urates; no germs or pus cells. Micturition is about every hour, accompanied with slight pain in the left lumbar region, where there is tenderness on pressure. The pain at times radiates to the testicle and end of penis. On rectal examination the prostate is found to be slightly enlarged. Diagnosis: Nephritic calculus probably passed into bladder.

March 8th (two days after admission): The hæmaturia is the same as when admitted. There are no casts nor any renal epithelium or organisms.-18th (twenty days after admission): The patient shows slight improvement, there being less blood. There is a little pus in the urine to-day; he complains of great pain at the end of the penis after micturition, also at the neck of the bladder; he cannot hold his urine longer than half an hour; no organisms.--19th: The patient was seen to-day by a surgeon, who thought perhaps the calculus from the kidney had been passed into the bladder ; consequently he submitted the bladder to an exploration with
Teevan's sound; but on attempting to withdraw the urine through the sound it was found that the plug was so fixed that it could not be removed. He therefore passed a red rubber catheter anointed with 1 in 20 of eucalyptus and olive oil The patient was given immediately afterwards five grains of quinine and thirty grains of bromide of soda. No stone could be discovered.-20th : Temperature this evening went up to $99 \cdot 4^{\circ}$; no rigor or any sensation of chilliness; pulse 60 (full); amount of urine passed sixty ounces; more pus and les blood than yesterday.-21st: This evening the temperature went up to $1032^{\circ}$. The patient complains of great thirst; amount of urine passed fifty ounces; pupils normal; no nervous phenomena; pulse 96 ; micturition less frequent.22nd: Temperature this morning $102^{\circ}$; at noon $1028^{\circ}$; at midnight $101^{\circ}$. Urine examined at bedside, immediately passed into a clean vessel, shows as follows: reaction alkaline, smells fetid. By microscope a large amount of pus cells, a few red cells, and many rod-shaped bacteria. Ordered five grains of sulphate of quinine with fifteen grains of benzoate of soda, every four hours. Water removed from bladder by syphon action. Less urine has been passed to-day. Ordered fomentations over loins and bladder.-23rd: Temperature this morning $100^{\circ}$. Says he feels better; not so thirsty; urine not so fetid, and contains less pus. He, however, sweats profusely, but has passed a better night, being in less pain. No action of bowels. Ordered colocynth with hyoscyamus pill (ten grains) at bed-time.--24th : Temperature: morning $998^{\circ}$; evening $101.4^{\circ}$. Sweats continue Urine still contains rod-shaped bacteria. Amount passed 100 ounces. Bowels moved three times.-25th : Temperature $97^{\circ} 4^{\circ}$, showing a marked fall; evening $994^{\circ}$. Amount of urine sixty ounces. Less pus; still fetid and contains bacteria. Sweats still present. Bowels moved once.-26th Temperature $99^{\circ}$. Amount of urine 100 ounces.

April 3rd.-The state of the patient's urine is much improved as regards bacteria, which, however, are still present, the urine continuing to be alkaline in reaction. He still complains of the old pain in the left lumbar region under cataplasm liniment to loins. - 4th: The old pain is still complained of this morning. In other respects he is in statu quo.

Remarks.--My term of office having expired, I lost sight of the patient, but I believe he left the hospital very much in the same condition as in the last report, the germs still remaining. The presence of the bacteria in the urine I believe to have been due to the employment of Teevan's sound, the interior of the instrument being probably dirty, and consequently loaded with septic germs. I think that this case plainly shows that the proper treatment of these septic bladder conditions is the drainage of the viscus by the syphon action, thus removing the major part of the bacteria, followed by large doses of quinine and benzoate of soda, in the hope of lessening the alkalinity of the urine, and with the hope of thus bringing about the death of the germs. Lastly, that fatal terminations may be looked for in such cases without probably much organic change in the kidneys, the cause of death not being uræmia, but septicæmia.

Duchess-street, $\mathbf{w}$.

\section{d altirror} or

\section{HOSPITAL PRACTICE, BRITISH AND FOREIGN.}

Nulla autem est alia pro certo noscendi via, nisi quamplurimas et morborum et dissectionum historias, tum aliorum tum proprias collectas habere, et inter se comparare. - MORGAGNI De Sed. et Caus. Morb., lib. iv, Procemin

\section{ST. THOMAS'S HOSPITAL.}

COMMUNICATION BETWEEN SMALL INTESTINE AND BLADDER; TUBERCULOSIS ; DEATH ; NECROPSY ; REMARKS.

(Under the care of Mr. Croft.)

Fisturous communication between the bladder and the intestinal tract above the rectum is usually the result of malignant ulceration which has extended from the sigmoid flexure into the bladder. Tubercular ulceration rarely produces such a condition. In this case the local signs were very few and the absence of chest symptoms, although 